\title{
IMPROVING THE HEALTH BENEFITS AND QUALITY OF LABNEH USING PROBIOTIC BACTERIA
}

\author{
K.M.K. Kebary(1), K.M. Kamaly(1), M.A. Mailam ${ }^{(2)}$ and A.G. Maamoon(2) \\ (1) Department of Dairy Sci. and Technol., Fac. Of Agric., Menoufiya university, shibin El- \\ Kom, Egypt. \\ (2) Dairy Res. Department, Food Research and Technology institute, Agricultural, Res. \\ Center.
}

Received: Jan. 5, 2021

Accepted: Jan. 17, 2021

\begin{abstract}
The effects of adding different strains from probiotic bacteria on the properties of Labneh were studied. Five Labneh treatments were made. Control Labneh treatment ( C) was made by inoculating the milk with $0.03 \%$ of freeze dried normal youghurt starter. Another three treatments were made by inoculating milk with $0.03 \%$ freeze dried normal youghurt starter plus $1.0 \%$ from each of Lactobacillus acidophilus (T1), Bifidobacterium bifidum (T2) and Lactobacillus plantarum (T3), while the fifth treatment was made by inoculating the milk with $0.03 \%$ freeze dried normal youghurt starter plus $0.33 \%$ from each of the previous three stains as a mixture. The obtained results revealed that the type of probiotic bacteria added during the manufacture of Labneh affected significantly $(p \leq 0.05)$ the chemical composition, microbiological, rheological and organoleptic properties of Labneh. Treatment (T4) that made with a mixture from probiotic bacteria contained the highest acidity, total solids, protein, fat, acetaldehyde and diacetyl followed by treatments T1 and T3 those made by adding L. acidophillus and $L$. plantarum respectively and then $T 2$ and $C$ treatments. Also treatment (T4) exhibited the highest values for Hardness, Adhesiveness, Cohesiveness, Springiness, Gumminess and Chewiness, which means improving the texture parameter, followed by Labneh treatments T1 and T2 and then T3 followed by C. Incorporating of probiotic bacteria improved the organoleptic properties and gained higher scores than control Labneh treatments. Although all Labneh treatments were accepted by the panelists, Labneh treatment (T3) that was made by adding L.plantarum gained the highest scores of organoleptic properties and was the most acceptable Labneh treatment T1 and T4, then T2, followed by treatments. Titratable acidity, total solids, protein, fat and ash contents and values of Hardness, Adhesiveness, Cohesiveness, Springiness, Gumminess and Chewiness increased during storage period, while $\mathrm{pH}$ values and lactose content decreased. Diacetyl and acetaldehyde content increased up to the seventh day of storage period then decreased as storage period proceeded. The counts of each probiotic bacteria even at the end of storage period was higher than the number should be present to achieve their health benefits, therefore Labneh could be a promising vehicle to deliver the probiotic bacteria to the consumers.
\end{abstract}

Key words: Labneh, probiotic bacteria, texture parameters, organoleptic properties.

\section{INTRODUCTION}

Labneh or strained/concentrated yogurt is a traditional fermented milk product. It is a popular food in various parts of the world, especially in the Middle East (Syria, Lebanon, Jordan and
Palestine). In recent years, the Labneh demand increased in Egypt. Labneh is a white to creamy paste that has a smooth texture, with a taste crossing between sour cream and cottage cheese and a properties sharp flavor that is largely modulated by diacetyl produced during 
fermentation (Tamime and Robinso, 1999). The total solids (TS) content is typically $23-25 \%$ and the product have a cream/white colour, a soft and smooth body, a good spread ability with little syneresis and a flavour that is clean and a little acidic (Rasic 1987).

Probiotics are defined as living microorganisms, are non-pathogenic which, when ingested in sufficient amounts, beneficially influence the health of the host by improving the composition of intestinal microflora. In addition to improving gut health, probiotics may play a beneficial role in several medical conditions, including lactose intolerance, cancer, allergies, hepatic disease, urinary tract infections, assimilation of cholesterol (Ejtahed et al., 2011). Such as lactic acid bacteria and yeasts used in fermentation procedures) which can be used in foods in order to improve the normal flora of host intestine (FAO/WHO, 2001).

The objective of this study were to evaluate the effect of adding L.acidophilus, Bifidobacterium bifidum and L.plantarum individually or a mixture from these bacteria on the physicochemical ,chemical, microbiological, rheological and organoleptic properties of Labneh and monitor the survival of probiotic bacteria and changes of Labneh qualities during the storage period.

\section{MATERIALS AND METHODS}

\section{Bacterial strains:}

Yoghurt starter Freeze dried conventional yoghurt starter culture (FDDVS YC-X11-Yo-Flex) containing Streptococcus thermophilus and Lactobacillus delbrueckii subsp. bulgaricus (1:1) was obtained from $\mathrm{Chr}$ Hansen,s Laboratories, Copenhagen, Denmark. The starter was directly added at ratio of $0.03 \%$ to the milk as recomended by the manufacturer, probiotic strains active Bifidobacterium bifidum (DSM 20082), was obtained from Cairo Mircen, Ain Shams University, Egypt. Lactobacillus plantarum (ATCC 14917), and Lactobacillus acidophilus (ATCC 20225) were obtained from Agricultural Research Center, Giza, Egypt. Lactobacillus plantarum and Lactobacillus acidophilus were activated individually by three successive transfers in sterile $10 \%$ reconstituted non-fat dry milk. Bifidobacterium bifidum was activated by three successive transfers in modified MRS broth medium (Ventling and Mistry, 1993), followed by three successive transfers in sterile $10 \%$ reconstituted non-fat dry milk and inoculated at $37^{\circ} \mathrm{C}$ under anaerobic condition.

\section{Manufacture of Labneh:}

Labneh was manufactured according to Robinson and Tamime (1994). Fresh buffalo's milk (5.5\% fat) was heated at $90^{\circ} \mathrm{C}$ for $10 \mathrm{~min}$, cooled to $42^{\circ} \mathrm{C}$ and then inoculated with $0.03 \%$ of the yoghurt starter culture (S. thermophilus $+\mathrm{L}$. bulgaricus). Then divided in to five treatments, one of them was made without probiotic bacteria and served as control (C); while the other four treatments were made by adding $1.0 \%$ from each of Lactobacillus plantarum, Bifidobacterium bifidum, Lactobacillus acidophilus and a mixture the previous bacteria ( $\% 0.33: 0.33: 0.33$ ) individually to the milk before incubating. Milk was incubated at $42^{\circ} \mathrm{C}$ until complete coagulation then the curd was poured into cheese cloth bags, which were hung in the refrigerator at $5+1^{\circ} \mathrm{C}$ for $18 \mathrm{~h}$, to allow drainage of the whey. The fresh labneh was packaged into small plastic containers and stored for 21 days at $5+$ $1^{\circ} \mathrm{C}$. Samples were taken from each Labneh treatment when fresh and at 7, 14, 21 days for chemical microbiological, rheological analysis and sensory 
evaluation. The whole experiment was triplicated.

\section{Microbiological analysis:}

Total bacterial counts were enumerated on nutrient agar medium according to Difco (1971). Lactobacillus plantarum counts were determined according to Bujalance et al. (2006), while Lactobacillus acidophilus counts were determined using MRS agar medium according to Dave and Shah (1996). Modified MRS agar medium was used to enumerate bifidobacteria (Ventling and Mistry, 1993) and NPNL solution was added to the medium before pouring plates (Samona and Robinson, 1991). Moulds and Yeasts were enumerated on acidified potato dextrose agar medium (Difco, 1953). Psychrotrophic bacterial counts were determined according to Cempírková (2002).

\section{Physiochemical analysis:}

The method of Lawrence (1968) was used to determined lactose. Titratable acidity, $\mathrm{pH}$ value and fat content were determined according to Ling (1963), while total solids, total protein and ash contents were determined according to A.O.A.C. (2012). Acetaldehyde and Diacetyl contents were determined according to the method described by Less and Jago(1969).

\section{Rheological analysis:}

Texture parameters were determined as describe by Bourne (1978) .

\section{Sensory evaluation:}

The labneh samples were evaluated by ten panelists of staff members of Agricultural Research Centre using the scheme of Salem et al. (2007), for flavour (50 points), Body \& texture (40 points), and appearance (10 points) on the $0,7,14$ and 21 days of cold storage at $6+1^{\circ} \mathrm{C}$.
Statistical analysis:

Data were analyzed using $2 \times 3$ factorial design. Newman-keels. Test was used to make the multiple comparisons (Steel and Torrie, 1980) using Costat Program. Significant were determined at $\mathrm{p} \leq 0.05$.

\section{RESULTS AND DISCUSSION}

\section{Chemical properties}

The obtained results indicated that titratable acidity of all labneh treatments increased significantly ( $p \leq 0.05)$ as storage period proceeded (Tables 1,7 ). This increase of titratable acidity might be due to the retaining of bacteria in labneh and increase their counts, which subsequently ferment more lactose to lactic acid. These results are in agreement with those reported by Abdalla and Abdel Nabi (2010), and Thabet et al. (2014). On the other hand, there were significant $(p \leq 0.05)$ differences among labneh treatments (Tables 1, 7), which means that the type of starter used in making of labneh affected significantly ( $p \leq 0.05)$ the titratable acidity of the resultant Labneh (Tables 1, 7). On the other hand, pH values as affected by probiotic bacteria and storage period followed on opposite trends of those of titratable acidity (Tables 1, 7), total protein and fat contents followed almost similar trends. There were significant $(p \leq 0.05)$ differences among Labneh treatments (Tables 2, 7), which means that the type of starter used in the manufacture of Labneh had significant ( $p \leq 0.05$ ) effect on the total solids, total protein and fat contents of the resultant Labneh (Tables 2,7) (Shaker et al., 2002 and Abd El-Salam et al., 2011and Ismail et al. (2017). These results might be due to increasing the acidity helps to expel the whey from the curd and consequently increase the total solids content of the resultant labneh treatments. Therefore, treatments that 
K. M. K. Kebary, et al.,

exhibited the highest acidity contained the highest total solids (Gün and Işıklı, 2007; Mahdian and Tehrani, 2007 and ElSayed et al., 2017). On the other hand, total solids, total protein and fat contents of all labneh treatments increased slightly as storage period advanced (Tables 2, 7), which might be due to the loss of moisture (Al-Otaibi and ElDemerdash, 2008, Atallah (2016) and Khodear (2018).

Table (1): Effect of adding probiotic bacteria on titratable acidity (\%) and $\mathrm{pH}$ values of Labneh stored at $6 \pm 1^{\circ} \mathrm{C}$ for 21 days.

\begin{tabular}{|c|c|c|c|c|c|c|c|c|}
\hline \multirow{2}{*}{$\begin{array}{c}\text { Labneh } \\
\text { Treatment* }\end{array}$} & \multicolumn{4}{|c|}{ Titratable acidity (\%) } & \multicolumn{4}{c|}{$\mathrm{pH}$ values } \\
\cline { 2 - 9 } & \multicolumn{3}{|c|}{ Storage period (days) } & \multicolumn{3}{c|}{ Storage period (days) } \\
\cline { 2 - 9 } & 0 & 7 & 14 & 21 & 0 & 7 & 14 & 21 \\
\hline $\mathrm{C}^{\curlyvee}$ & 1.25 & 1.29 & 1.33 & 1.36 & 4.52 & 4.38 & 4.25 & 4.14 \\
\hline $\mathrm{T}_{1}$ & 1.34 & 1.44 & 1.49 & 1.5 & 4.28 & 4.15 & 3.99 & 3.9 \\
\hline $\mathrm{T}_{2}$ & 1.27 & 1.31 & 1.36 & 1.39 & 4.44 & 4.25 & 4.16 & 4.07 \\
\hline $\mathrm{T}_{3}$ & 1.3 & 1.38 & 1.43 & 1.45 & 4.41 & 4.2 & 4.08 & 4 \\
\hline $\mathrm{T}_{4}$ & 1.36 & 1.52 & 1.56 & 1.62 & 4.14 & 4 & 3.89 & 3.77 \\
\hline
\end{tabular}

$\mathrm{C}^{\diamond}$ : Control labneh made by adding $0.03 \%$ freeze dried conventional yoghurt starter culture containing Streptococcus thermophilus and Lactobacillus delbrueckii subsp. bulgaricus (1:1).

$\mathrm{T}_{1}$ : Labneh made by adding $0.03 \%$ freeze dried conventional yoghurt starter culture $+1.00 \%$ Lactobacillus acidophilus.

$\mathrm{T}_{2}$ : Labneh made by adding $0.03 \%$ freeze dried conventional yoghurt starter culture $+1.00 \%$ Bifidobacterium bifidum.

$T_{3}$ : Labneh made by adding $0.03 \%$ freeze dried conventional yoghurt starter culture $+1.00 \%$ Lactobacillus plantarum.

$\mathrm{T}_{4}$ : Labneh made by adding $0.03 \%$ Freeze dried conventional yoghurt starter culture $+0.33 \%$ from each of $L$. acidophilus, Bifidobacterium bifidum and $L$. plantarum.

Table (2): Effect of adding probiotic bacteria on gross composition of Labneh stored at 6 $\pm 1^{\circ} \mathrm{C}$ for 21 days.

\begin{tabular}{|c|c|c|c|c|c|c|c|c|c|c|c|c|c|c|c|c|}
\hline \multirow{3}{*}{$\begin{array}{l}\text { Labneh } \\
\text { Treatments }\end{array}$} & \multicolumn{4}{|c|}{$\begin{array}{c}\text { Total Solids } \\
\text { (\%) }\end{array}$} & \multicolumn{4}{|c|}{$\begin{array}{c}\text { Total Protein } \\
\text { (\%) }\end{array}$} & \multicolumn{4}{|c|}{$\begin{array}{l}\text { Fat } \\
\text { (\%) }\end{array}$} & \multicolumn{4}{|c|}{$\begin{array}{l}\text { Ash } \\
(\%)\end{array}$} \\
\hline & \multicolumn{4}{|c|}{$\begin{array}{c}\text { Storage period } \\
\text { (days) }\end{array}$} & \multicolumn{4}{|c|}{$\begin{array}{l}\text { Storage period } \\
\text { (days) }\end{array}$} & \multicolumn{4}{|c|}{$\begin{array}{c}\text { Storage period } \\
\text { (days) }\end{array}$} & \multicolumn{4}{|c|}{$\begin{array}{l}\text { Storage period } \\
\text { (days) }\end{array}$} \\
\hline & 0 & 7 & 14 & 21 & 0 & 7 & 14 & 21 & 0 & 7 & 14 & 21 & 0 & 7 & 14 & 21 \\
\hline Control & 25.75 & 25.96 & 26.14 & 26.19 & 9.1 & 9.15 & 9.18 & \begin{tabular}{|l|}
9.2 \\
\end{tabular} & $\mid 11.5$ & 11.6 & 11.7 & $\mid 11.8$ & 1.7 & 1.8 & 1.88 & 1.9 \\
\hline$T_{1}$ & 26.39 & 26.5 & 26.69 & 26.97 & 9.3 & 9.34 & 9.37 & 9.41 & 12.2 & 12.3 & 12.5 & $\mid 12.8$ & 1.54 & 1.58 & 1.64 & 1.66 \\
\hline$T_{2}$ & 26.23 & 26.45 & 26.54 & 26.75 & 9.15 & 9.19 & $|9.24|$ & 9.26 & 12 & 12.2 & 12.3 & 12.5 & 1.65 & 1.68 & 1.7 & 1.75 \\
\hline$T_{3}$ & 27.05 & 27.11 & 27.12 & 27.19 & 9.26 & 9.29 & $|9.31|$ & 9.35 & $\mid 12.8$ & 12.9 & 12.9 & 13 & 1.59 & $|1.61|$ & 1.67 & 1.69 \\
\hline$T_{4}$ & 27.1 & 27.6 & 27.77 & 27.93 & 9.4 & 9.35 & 9.47 & 9.7 & $\mid 12.9$ & 13 & 13.4 & 13.6 & 1.5 & 1.54 & 1.6 & 1.63 \\
\hline
\end{tabular}

* Each value in the table was the mean of three replicates.

$\diamond$ See Table (1). 
The ash and lactose contents of Labneh treatments followed almost similar trends (Tables 2,3,7). There were significant ( $p \leq 0.05$ ) differences among Labneh treatments (Tables 2,3,7), which might be due to the differences in the titratable acidity of Labneh treatments. There is a negative correlation between the ash and lactose contents and the titratable acidity of Labneh treatments. Labneh treatments that had the highest titratable acidity contained the lowest ash and lactose contents (Tables 2,3,7), which might be due to dissolving some minerals by acidity and consequently loss these minerals in whey and subsequently decreases the ash content of the resultant Labneh treatments (Nergiz and Seckin, 1998 and Nsabimana et al., 2005), who reported that, the important losses occurred during manufacture and the highest losses were for minerals such as $\mathrm{Na}, \mathrm{K}, \mathrm{Ca}$ and $\mathrm{P}$. Ash content of all Labneh treatments increased slightly as storage period proceeded (Tables 2,7). The increase may be due to the increase of total solids contents during the storage period. Similar trends were reported by El-Alfy et al. (2011) and Atallah (2016). The lactose content of all Labneh treatments decreased significantly $(p \leq 0.05)$ as storage period proceeded (Tables 3,7 ). The reduction of Lactose during storage could be attributed to the activity of lactic acid bacteria those ferment lactose to lactic acid during storage (Omer and Eltinay, 2009 and Ghalem and Zouaoui, 2013).

\section{Acetaldehyde content}

Changes of Acetaldehyde content during storage period of Labneh made with different starter are presented in Table (3). The diacetyl content of Labneh treatments followed similar trends of those of the actaldehyde content. The obtained results indicated that the acetaldehyde and diacetyl contents of all Labneh treatments increased during the first 7 days of storage period and reached their maximum concentration on the seventh day of storage period, then decreased gradually up to the end of storage period (Tables 3, 7). The reduction of acetaldehyde might be due to the reduction to ethanol (Tamime and Robinsonm, 1983 and El-Samragy et al., 1988). Similar trends were reported by Soad et al. (1997) and Al-Otaibi and ElDemerdash (2008), while decreasing of diacetyl might be due the reduction of diacetyl to acetone (Cogan, 1971). These results are in agreement with result reported for yoghurt by Badran (1986), Kebary et al. (2010) ), Hamed et al. (2020). Labneh treatments were significant ( $p \leq$ 0.05) different from each other in the concentration of acetaldehyde and diacetyl contents, which means that the type of starter used in the manufacture of Labneh affected significantly ( $p \leq 0.05$ ) the acetaldehyde and diacetyl contents of the resultant Labneh treatments (Tables3, 7 ). These results might be due to the different ability of each starter used in making Labneh in the production of the acetaldehyde and diacetyl (Soad et al., 1997 and Al-Otaibi and El-Demerdash, 2008). These microorganisms can ferment milk lactose to lactic acid, acetaldehyde and diacetyl (Hamdan et al., 1971 and Amarita et al., 2001). Treatment T4 that was made by starter containing $L$. acidophilus + Bif. bifidum + L. plantarum and treatment T3 that was made by L.plantarum contained the highest acetaldehyde and diacetyl contents were significantly different from other labneh treatments. These results might be due to the synergistic effects of these bacteria on their growth and consequently increasing the production of acetaldehyde and diacetyl. 
Table (3): Effect of adding probiotic bacteria on Lactose, acetaldehyde and diacetyl content of Labneh stored at $6 \pm 1^{\circ} \mathrm{C}$ for 21 days.

\begin{tabular}{|c|c|c|c|c|c|c|c|c|c|c|c|c|}
\hline \multirow{2}{*}{$\begin{array}{c}\text { Labneh } \\
\text { Treatment }\end{array}$} & \multicolumn{3}{|c|}{ lactose content (\%) } & \multicolumn{3}{c|}{ acetaldehyde content (ppm) } & \multicolumn{3}{l|}{ Diacetyl content } \\
\cline { 2 - 12 } & \multicolumn{2}{l}{ Storage period (days) } & \multicolumn{3}{|c|}{ Storage period (days) } & \multicolumn{4}{|c|}{ Storage period (days) } \\
\cline { 2 - 13 } & 0 & 7 & 14 & 21 & 0 & 7 & 14 & 21 & 0 & 7 & 14 & 21 \\
\hline Control & 3.45 & 3.41 & 3.38 & 3.29 & 24.28 & 39.14 & 30.74 & 25.69 & 7.84 & 12.47 & 11.58 & 9.61 \\
\hline $\mathrm{T}_{1}$ & 3.35 & 3.28 & 3.18 & 3.1 & 48.54 & 52.12 & 50.47 & 47.14 & 27.14 & 32.82 & 29.53 & 22.1 \\
\hline $\mathrm{T}_{2}$ & 3.43 & 3.38 & 3.3 & 3.24 & 40.98 & 49.05 & 43.36 & 40.6 & 20.25 & 29.11 & 20.08 & 15.52 \\
\hline $\mathrm{T}_{3}$ & 3.4 & 3.31 & 3.24 & 3.15 & 51.96 & 55.87 & 53.67 & 50.32 & 27.97 & 33.71 & 30 & 28.22 \\
\hline $\mathrm{T}_{4}$ & 3.3 & 3.2 & 3.1 & 3 & 59.48 & 64.71 & 57.98 & 52.58 & 29.51 & 35.12 & 32.79 & 30.94 \\
\hline
\end{tabular}

* Each value in the table was the mean of three replicates.

$\diamond$ See Table (1).

Rheological properties It has been claimed that the manufacturing techniques and the total solids and total protein of Labneh had crucial effects on the rheology of Labneh (Nsabimana et al., 2005). The values of texture profile analysis of fresh Labneh and after 21 days of storage are presented in Table (4). The obtained results indicated that the texture parameters (Hardness, Adhesiveness, Cohesiveness, Springiness, Gumminess and Chewiness) followed almost similar trends (Tables 4, 8). There were significant difference among Labneh treatments in the values of Hardness, Adhesiveness, Cohesiveness, Springiness, Gumminess and Chewiness (texture parameters), which means that the starter culture affected significantly the rheological properties of the resulting Labneh. Treatment T4 that contained the highest total solids and total protein contents exhibited the highest values of texture parameters, while Treatment C which contained the lowest total solids and total protein contents exhibited the lowest values of texture parameters. These results might be due to the differences of total solids and total protein contents of Labneh treatments (Nsabimana et al., 2005; Saad et al., 2015 and El-Sayed et al., 2017) who stated that the rheological behavior of Labneh depended on the protein concentration.

On the other hand, most texture parameters of all Labneh treatments increased slightly while adhesiveness and springiness decreased slightly during the storage period (Tables 4,8 ). These results might be due to the increase of total solids and total protein contents of all Labneh treatments as storage period proceeded. Similar trends were obtained by Mohamed et al. (2015), Mailam (2015), El-Sayed et al. (2017), Ibrahim (2017) and Ali (2018).

Changes of total bacterial counts during storage of Labneh treatments are presented in Table (5). The obtained results indicated that incorporating of probiotic bacteria caused a significant increase of the total bacterial counts of 
the resulting Labneh treatments, which might be due to these bacteria were added beside addition of the normal yoghurt starter. Labneh treatment T4 exhibited the highest total bacterial counts, which might be due to the synergistic effect of these probiotic bacteria on each other. Total bacterial counts of Labneh treatments were different from each other, which might be due to the different abilities of producing antimicrobial agents thus suppress the growth of bacteria and consequently decrease the count of total bacteria and/or different ability to tolerate the developed acidity (Lorca et al., 2002 and Azcarate-Peril et al., 2004). Total bacterial counts of all Labneh treatments increased and reached their maximum counts on the seventh day of storage, then they were declined up to the end of storage period (Table 5), which might be due to the effect of the developed acidity and cold storage. Similar trends were reported by Al-Otaibi and El-Demerdash (2008), Nasser et al. (2017) and Abdelsattar et al. (2019).

Table (4): Effect of adding probiotic bacteria on texture parameters of Labneh stored at $6 \pm 1^{\circ} \mathrm{C}$ for 21 days.

\begin{tabular}{|c|c|c|c|c|c|c|}
\hline $\begin{array}{c}\text { Labneh } \\
\text { Treatments* }\end{array}$ & 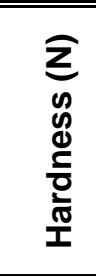 & 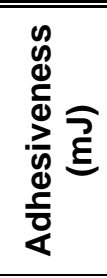 & 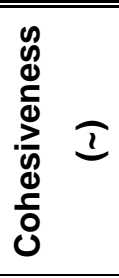 & 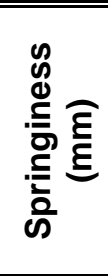 & 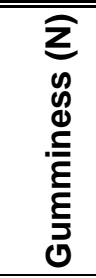 & 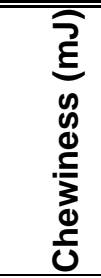 \\
\hline & \multicolumn{6}{|c|}{0} \\
\hline $\mathbf{C}^{\diamond}$ & 5 & 5.3 & 0.28 & 4.8 & 1.4 & 6.72 \\
\hline $\mathrm{T}_{1}$ & 6.4 & 4.2 & 0.45 & 4.00 & 2.88 & 11.52 \\
\hline $\mathrm{T}_{2}$ & 6.2 & 4.8 & 0.33 & 4.6 & 2.04 & 9.41 \\
\hline $\mathbf{T}_{3}$ & 6.35 & 4.5 & 0.41 & 4.3 & 2.60 & 11.19 \\
\hline $\mathrm{T}_{4}$ & 6.8 & 4.00 & 0.51 & 3.8 & 3.46 & 13.17 \\
\hline \multicolumn{7}{|c|}{21} \\
\hline $\mathbf{C}^{\diamond}$ & 6.00 & 4.8 & 0.33 & 4.5 & 1.98 & 8.91 \\
\hline$T_{1}$ & 8.8 & 3.9 & 0.54 & 3.9 & 4.75 & 18.53 \\
\hline$T_{2}$ & 7.00 & 4.4 & 0.46 & 4.3 & 3.22 & 13.84 \\
\hline$T_{3}$ & 8.6 & 4.00 & 0.50 & 4.00 & 4.3 & 15.48 \\
\hline $\mathrm{T}_{4}$ & 9.00 & 3.2 & 0.62 & 3.6 & 5.58 & 20.08 \\
\hline
\end{tabular}

* Each value in the table was the mean of three replicates.

$\checkmark$ See Table (1). 
K. M. K. Kebary, et al.,

Table (5): Effect of adding probiotic bacteria on microbiological behaviour of Labneh stored at $6 \pm 1^{\circ} \mathrm{C}$ for 21 days.

\begin{tabular}{|c|c|c|c|c|c|c|}
\hline $\begin{array}{l}\text { Labneh } \\
\text { Treatments }\end{array}$ & T.C & $\begin{array}{l}\text { Lb. } \\
\text { acidophilus }\end{array}$ & $\begin{array}{c}\text { Bif. } \\
\text { bifidum }\end{array}$ & $\begin{array}{c}\text { Lb. } \\
\text { plantarum }\end{array}$ & $\begin{array}{c}\text { Mould and } \\
\text { yeast }\end{array}$ & Psy.c. \\
\hline \multicolumn{7}{|c|}{0} \\
\hline $\mathbf{C}^{\diamond}$ & 7.42 & ----- & --.- & ----- & ND & ND \\
\hline$T_{1}$ & 9.20 & 8.52 & ----- & ----- & ND & ND \\
\hline$T_{2}$ & 8.74 & ---- & 7.1 & ---- & ND & ND \\
\hline$T_{3}$ & 9.00 & ----- & ----- & 8.00 & ND & ND \\
\hline$T_{4}$ & 9.38 & 7.77 & 6.00 & 7.12 & ND & ND \\
\hline \multicolumn{7}{|c|}{7} \\
\hline $\mathbf{C}^{\diamond}$ & 7.78 & ---- & ----- & ---- & ND & ND \\
\hline$T_{1}$ & 9.51 & 8.64 & $-\cdots$ & ---- & ND & ND \\
\hline$T_{2}$ & 8.98 & ---- & 7.24 & ---- & ND & ND \\
\hline$T_{3}$ & 9.25 & ----- & ----- & 8.44 & ND & ND \\
\hline$T_{4}$ & 9.70 & 7.81 & 6.36 & 7.45 & ND & ND \\
\hline \multicolumn{7}{|c|}{14} \\
\hline $\mathbf{C}^{\diamond}$ & 7.7 & ---- & ----- & ---- & 2.00 & ND \\
\hline$T_{1}$ & 9.42 & 8.61 & ---- & ---- & ND & ND \\
\hline$T_{2}$ & 8.79 & ---.- & 7.12 & ---- & 2.5 & ND \\
\hline$T_{3}$ & 9.1 & ---- & ---- & 8.34 & ND & ND \\
\hline $\mathrm{T}_{4}$ & 9.61 & 7.72 & 6.20 & 7.34 & ND & ND \\
\hline \multicolumn{7}{|c|}{21} \\
\hline $\mathbf{C}^{\diamond}$ & 7.20 & ---- & - --- & ---- & 3.4 & ND \\
\hline$T_{1}$ & 9.00 & 8.43 & ---- & ---- & ND & ND \\
\hline$T_{2}$ & 8.5 & --.-- & 7.00 & ---- & 2.9 & ND \\
\hline$T_{3}$ & 8.8 & ---- & ----- & 8.29 & ND & ND \\
\hline$T_{4}$ & 9.20 & 7.51 & 6.12 & 7.00 & ND & ND \\
\hline
\end{tabular}

T.C = Total bacterial counts.

Psy.C.= Counts of psyhrotrophic bacteria.

$\diamond$ See Table (1). $\quad$ ND = Not detected.

--- Not determined

The count of each probiotic bacteria (L. acidophilus, Bif. bifidum and $L$. plantarum) was determined in Labneh treatments those were made by adding each bacterial strain (Table 5). Labneh treatments $\mathrm{T} 1, \mathrm{~T} 2$ and $\mathrm{T} 3$ exhibited higher counts of $L$. acidophilus, Bif. bifidum and L. Plantarum, respectively, than those of treatment T4 in the same order, which might be due to the amount added of these bacteria during the manufacture of Labneh treatments (Table 5). Comparing the counts of each bacterial strains, the counts of $L$. acidophilus were the highest followed by the counts of L. plantarum and then the count of Bif. bifidum. These results might be due to the ability to tolerate the development of acidity, whereas $L$. acidophilus could tolerate the acidity, on the contrary the growth of Bif. bifidum could be affected by acidity (Dave and Shah, 1997; Kailasapathy and Rybka, 1997; Lorca et al., 2002 and Azcarate-Peril et al., 2004). The probiotic bacteria followed almost similar trends (Table 5), all probiotic bacteria increased and reached their maximum counts on the seventh day of storage then their counts were reduced as the storage period progressed (Table 5), which might be due to the cold storage and/or the developed acidity. Similar results were reported by Martin and Choe (1992), Kebary et al. (2008), Abd-Elsatar et al. 
(2019). The counts of each probiotic strain even after 21 days of storage were higher than the counts of these bacteria should be present to achieve their health benefits for the consumers (106), therefore, probiotic Labneh could be a good product for delivering the probiotic bacteria to the consumers.

Data in Table (5) show that moulds and yeasts were not detected in all Labneh treatments during the first 7 days of storage, which might be due to following good hygienic conditions during the manufacture of Labneh. Moulds and yeasts appeared on the fourteenth day of storage in control Labneh treatment and T2 that was made by adding Bif. bifidum and increased towards the end of storage period (Table 5). On the other hand, moulds and yeasts were not detected in Labneh treatments those made by adding L. acidophilus or L. plantarum which might be due to the production of antimicrobial agents, especially antifungal agents (Ghazvini et al., 2016; Russo et al., 2017 and Radi et al., 2017). Psychrotrophic bacteria were not detected in all Labneh treatments at any time of storage period (Table 5) (Yu et al., 2013 and Ołdak et al., 2017).

Scores of organoleptic properties (flavours, body and texture and appearance of all Labneh treatments are presented in Table (6). Scores of flavour, body and texture and the total scores of organoleptic properties, followed similar trends (Tables 6 and 9). The obtained results indicated that there were significant $(p \leq 0.05)$ differences among Labneh treatments, which means that the type of starter affected the scores of organoleptic properties (Tables 6, 9). Incorporation of probiotic bacteria during the manufacture of Labneh treatments improved their acceptability and subsequently increased the scores of flavour, body and texture and the total scores (Tables 6, 9). Although all Labneh treatments were accepted by the panelist, T3 that made by adding L. plantarum was the most acceptable Labneh treatment and gained the highest scores of organoleptic properties (Sharal et al., 1996). On the other hand, scores of organoleptic properties did not change significantly during the first 7 days of storage period, then the scores were declined up to the end of storage period (Tables 6, 9). These results are in agreement with those reported by AlOtaibi and El-Demerdash (2008), Salem et al. (2013), El-Sayed et al. (2017), Nasser et al. (2017), Abd El-Sattar et al. (2019).

It could be concluded that incorporation of probiotic bacteria during the manufacture of Labneh increased the titratable acidity, total solids, protein, fat, acetaldehyde and diacetyl contents of the resulting Labneh treatments, while decreasing the ash and lactose contents. It also increased all the values of texture parameters (hardness, Adhesiveness, Cohesiveness, Springiness, Gumminess and Chewiness), viscosity and improved the acceptability of Labneh treatments. The most acceptable treatment was T3 that was made by adding L. plantarum. On the other hand, total solids, fat, total protein contents, titratable acidity, texture parameters, viscosity increased slightly during the storage period, while $\mathrm{pH}$ values were decreased. The counts of probiotic bacteria of Labneh treatments those made by adding these bacteria, even at the end of storage period were higher than the numbers should be present in food products to achieve their health benefits. Therefore, probiotic Labneh could be a good vehicle for delivering the probiotic bacteria to consumers. 
K. M. K. Kebary, et al.,

Table (6): Effect of adding probiotic bacteria on sensory evaluation of Labneh stored at 6 $\pm 1^{\circ} \mathrm{C}$ for 21 days.

\begin{tabular}{|c|c|c|c|c|}
\hline Labneh Treatments & $\begin{array}{c}\text { Flavour } \\
(50)\end{array}$ & Body \& texture (40) & Appearance (10) & Total \\
\hline & \multicolumn{4}{|c|}{0} \\
\hline $\mathbf{C}^{\diamond}$ & 41 & 37 & 10 & 88 \\
\hline $\mathbf{T}_{1}$ & 46 & 39 & 10 & 95 \\
\hline$T_{2}$ & 43 & 38 & 10 & 91 \\
\hline$T_{3}$ & 49 & 40 & 10 & 99 \\
\hline \multirow[t]{2}{*}{$T_{4}$} & 45 & 38 & 10 & 93 \\
\hline & \multicolumn{4}{|c|}{7} \\
\hline $\mathbf{C}^{\diamond}$ & 41 & 37 & 9 & 87 \\
\hline $\mathbf{T}_{1}$ & 46 & 39 & 9 & 94 \\
\hline$T_{2}$ & 43 & 38 & 9 & 90 \\
\hline$T_{3}$ & 49 & 40 & 9 & 98 \\
\hline \multirow[t]{2}{*}{$\mathrm{T}_{4}$} & 45 & 38 & 9 & 92 \\
\hline & \multicolumn{4}{|c|}{14} \\
\hline $\mathbf{C}^{\diamond}$ & 39 & 31 & 6 & 76 \\
\hline $\mathbf{T}_{1}$ & 44 & 35 & 7 & 86 \\
\hline $\mathbf{T}_{2}$ & 41 & 33 & 6 & 80 \\
\hline$T_{3}$ & 47 & 38 & 8 & 93 \\
\hline \multirow[t]{2}{*}{$\mathbf{T}_{4}$} & 42 & 34 & 6 & 82 \\
\hline & \multicolumn{4}{|c|}{21} \\
\hline $\mathbf{C}^{\diamond}$ & 34 & 29 & 6 & 69 \\
\hline$T_{1}$ & 39 & 33 & 6 & 78 \\
\hline $\mathbf{T}_{2}$ & 37 & 31 & 6 & 74 \\
\hline$T_{3}$ & 44 & 35 & 7 & 86 \\
\hline $\mathbf{T}_{4}$ & 35 & 32 & 6 & 73 \\
\hline
\end{tabular}

$\diamond$ See Table (1).

Table (7). Statistical analysis of chemical composition of Labneh stored at $6 \pm 1^{\circ} \mathrm{C}$ for 21 days.

\begin{tabular}{|c|c|c|c|c|c|c|c|c|c|c|c|}
\hline \multirow{3}{*}{$\begin{array}{l}\text { Labneh } \\
\text { properties }\end{array}$} & \multirow{2}{*}{\multicolumn{6}{|c|}{$\begin{array}{l}\text { Effect of treatments } \\
\text { Multiple comparison }\end{array}$}} & \multirow{2}{*}{\multicolumn{5}{|c|}{$\begin{array}{l}\text { Effect of storage period (days) } \\
\text { Multiple comparison' }\end{array}$}} \\
\hline & & & & & & & & & & & \\
\hline & $\begin{array}{c}\text { Mean } \\
\text { Squares }\end{array}$ & $\mathbf{C}^{\diamond}$ & $\mathrm{T}_{1}$ & $T_{2}$ & $T_{3}$ & $T_{4}$ & $\begin{array}{c}\text { Mean } \\
\text { Squares }\end{array}$ & 0 & 7 & 14 & 21 \\
\hline Acidity & $0.156^{*}$ & $E$ & B & D & C & A & $0.349^{*}$ & D & C & B & A \\
\hline pH & $0.010^{*}$ & $\mathbf{A}$ & D & B & C & $E$ & $0.019^{*}$ & $\mathbf{A}$ & B & C & D \\
\hline Total solid & $2.703^{*}$ & D & B & CD & C & A & $16.008^{*}$ & C & BC & $\overline{A B}$ & $A$ \\
\hline Protein & $2.568^{*}$ & D & $A B$ & CD & B C & A & $12^{*}$ & C & BC & $A B C$ & A \\
\hline Fat & $17.400^{*}$ & D & $A B$ & C & B & $\mathbf{A}$ & $65.126^{*}$ & C & BC & ABC & $\mathbf{A}$ \\
\hline Ash & $0.010^{*}$ & A & CD & AB & BC & D & $0.213^{*}$ & C & BC & $A B$ & A \\
\hline Lactose & $0.055^{*}$ & A & D & B & C & $\mathrm{E}$ & $0.105^{*}$ & A & B & C & D \\
\hline Acetaldehyde & $2421.97^{*}$ & D & B & C & $A B$ & $\mathbf{A}$ & 126.313* & D & $\mathbf{A}$ & B & C \\
\hline Diacetyl & $1390.06^{*}$ & D & B & C & $A B$ & A & $52.036^{*}$ & D & A & B & C \\
\hline
\end{tabular}

$\diamond$ See Table (1).

- For each effect the different letters in the same row means the multiple comparisons are different from each other, letter $A$ is the highest mean followed by $B, C, \ldots$ etc.

* Significant at 0.05 levels $(p \leq 0.05)$. 
Table (8). Statistical analysis of rheological properties of Labneh stored at $6 \pm 1^{\circ} \mathrm{C}$ for 21 days.

\begin{tabular}{|c|c|c|c|c|c|c|c|c|c|}
\hline \multirow{3}{*}{ Texture parameters } & \multicolumn{6}{|c|}{ Effect of treatments } & \multicolumn{3}{|c|}{ Effect of storage } \\
\hline & \multicolumn{6}{|c|}{ Multiple comparison` } & \multicolumn{3}{|c|}{$\begin{array}{c}\text { Multiple } \\
\text { comparison }\end{array}$} \\
\hline & $\begin{array}{c}\text { Mean } \\
\text { Squares }\end{array}$ & $\mathbf{C}^{\diamond}$ & $\mathbf{T}_{1}$ & $T_{2}$ & $\mathbf{T}_{3}$ & $\mathbf{T}_{4}$ & $\begin{array}{l}\text { Mean } \\
\text { Squares }\end{array}$ & 0 & 21 \\
\hline Hardness (N) & $0.593^{*}$ & D & B & C & B & A & $5.043^{*}$ & B & A \\
\hline Adhesiveness (mJ) & $2.986 *$ & D & B & C & B & A & $40.549 *$ & A & B \\
\hline Cohesiveness ( ) & $0.057^{*}$ & C & $A B$ & C & B & A & $0.097^{*}$ & B & A \\
\hline Springiness (mm) & $1.652^{*}$ & D & $A B$ & C & B & A & $119.520 *$ & A & B \\
\hline Gumminess (N) & $0.199 *$ & C & $A B$ & BC & $A B$ & A & $2.403^{*}$ & B & A \\
\hline Chewiness (mJ) & 8.896* & D & $A B$ & C & B & A & $1.786^{*}$ & B & A \\
\hline
\end{tabular}

$\diamond$ See Table (1).

- For each effect the different letters in the same row means the multiple comparisons are different from each other, letter $A$ is the highest mean followed by $B, C, \ldots$ etc.

* Significant at 0.05 levels ( $p \leq 0.05)$.

Table (9). Statistical analysis of sensory evaluation of Labneh stored at $6 \pm 1^{\circ} \mathrm{C}$ for 21 days.

\begin{tabular}{|c|c|c|c|c|c|c|c|c|c|c|c|}
\hline \multirow{3}{*}{$\begin{array}{l}\text { Labneh } \\
\text { properties }\end{array}$} & \multicolumn{6}{|c|}{ Effect of treatments } & \multicolumn{5}{|c|}{ Effect of storage period (days) } \\
\hline & \multicolumn{6}{|c|}{ Multiple comparison } & \multicolumn{5}{|c|}{ Multiple comparison` } \\
\hline & $\begin{array}{c}\text { Mean } \\
\text { Squares }\end{array}$ & $\mathbf{C}^{\diamond}$ & $\mathrm{T}_{1}$ & $\mathbf{T}_{2}$ & $\mathbf{T}_{3}$ & $\mathbf{T}_{4}$ & $\begin{array}{c}\text { Mean } \\
\text { Squares }\end{array}$ & 0 & 7 & 14 & 21 \\
\hline Flavour & 91.125* & D & B & C & A & B & $228.550 *$ & A & A & B & C \\
\hline Body\& texture & $99.375^{*}$ & D & B & C & A & B & $114.950 *$ & A & A & B & C \\
\hline Appearance & $0.600 *$ & B & AB & AB & A & AB & $37.350 *$ & A & A & B & C \\
\hline Total & $273.525^{*}$ & D & B & C & A & B & 939.200* & $A$ & $A$ & B & C \\
\hline
\end{tabular}

$\diamond$ See Table (1).

- For each effect the different letters in the same row means the multiple comparisons are different from each other, letter $A$ is the highest mean followed by $B, C, \ldots$. etc.

* Significant at 0.05 levels ( $p \leq 0.05)$.

\section{REFERENCE}

A.O.A.C (2012). Official Methods of Analysis. of Association of Official Analytical Chemists. $19^{\text {th }}$ Ed. Published by Association of Official Analytical Chemists, Washington. D.C. (USA).

Abd El-Salam, M.H., A.R. Hippen, K. El-Shafie, F.M. Assem, H. Abbas, M.
Abd El-Aziz and El-Aassar, M. (2011). Preparation and properties of probiotic concentrated yoghurt (labneh) fortified with conjugated linoleic acid. Food Sci. Technol. 46: 2103 - 2110.

Abd El-Sattar, E., E.M. Abd El-Wahed and A.H. Ali (2019). Effect of oat flour supplement action on the 
physicochemical, microbiological and organoleptic properties of low fat probiotic Labneh. Egyptian J. Dairy Sci., 47: 101 - 109.

Abdalla, O.M. and A.S.Z. Abdel Nabi (2010). Chemical Composition of Mish "A Traditional Fermented Dairy Product" from Different Plants during Storage. Pak. J. Nutr., 9: 209 - 212.

Ali, A.R.M. (2018). Incorporating of some natural and bio-materials in cheese making to improve their functional characteristics. Ph.D. Thesis, Fac. Agric., Moshtohor, Benha Univ., Egypt.

Al-Otaibi, M. and H. El Demerdash (2008). Improvement of the quality and shelf life of concentrated yoghurt (labneh) by the addition of some essential oils. African Microbiol. Res., 2: 156 161.

Amarita, F., T. Requenai, G. Tabordaz, L. Amigo and C. Pelaez (2001). Lactobacillus casei and Lactobacillus plantarum initiate catabolism of methionine by transamination. J. Appl. Microbiol., 90: 971 - 978.

Atallah, A.A. (2016). The production of bio-yoghurt with probiotic bacteria, royal jelly and bee pollen grains. $J$. Nutr. Food Sci., 6: 5 - 7.

Azcarate-Peril, M.A., E. Altermann, R.L. Hoover-Fitzula, R. Cano and T.R. Klaenhammer (2004). Identification and inactivation of genetic loci involved with Lactobacillus acidophilus acid tolerance. Appl. Environ. Microbiol., 70: 5315 - 5322.

Badran, I. (1986). Studies on the use of soybean protein in yoghurt making. M.Sc. Thesis, Food Sci., Faculty of Agric., Menoufia Univ., Egypt, 3: 79 91.

Bourne, M.C. (1978). Food Texture and Viscosity. Academic Press, New York (reprinted 1994), p. 416.
Bujalance, C., M. Jiménez-Valera, E. Moreno and A. Ruiz-Bravo (2006). A selective differential medium for Lactobacillus plantarum. J. Microbiol. Meth., 66: 572 - 575.

Cempírková, R. (2002). Psychrotrophic vs. total bacterial counts in bulk milk samples. Veterinarni Medicina-Praha, $47: 227$ - 233.

Cogan, T.M. (1971). Modification of the Prill and Hammer method for determining diacetyl. J. Dairy Sci., 55: 382 - 384.

Dave, R.I. and N.P. Shah (1997). Viability of yoghurt and probiotic bacteria in yoghurts made from commercial starter cultures. Int. Dairy J., 7: 31 41.

Difco, (1971). Difco Manual of Dehydrated Culture Media and Reagents for Microbial and Clinical Laboratory Procedures $9^{\text {th }}$ Ed.; Rep. 1971. Difco Laboratories Incorporated, Detriot, Michigan, USA.

Difco Manual (1953). Dehydrated culture media and reagents $9^{\text {th }}$ ed. Difcolabortories, Detriot, Michingan.

Ejtahed, H., N. J. Mohtadi, R. A. Homayouni, M. Niafar, J. M. Asghari, V. Mofid and M. A. Akabarian (2011). Effect of probiotic yogurt containing Lactobacillus acidophilus and Bifidobacterium lactis on lipid profile in individuals with type 2 diabetes mellitus. J. Dairy Sci., 94: 3288 - 3294.

El-Alfy, M.B., M.E. Shenana, A.M. Abd ElAty and E.S. El-Khtab (2011). Antibacterial activity of some natural preservative materials and their effects on characteristics of yoghurt. Egypt. J. App. Sci., 26 (12B): 343 360.

El-Samragy, Y.A., E.O. Fayed, A.A. Ali and A.E. Hagrass (1988). Properties of labneh-like product manufactured using Enterococcus starter cultures 
as novel dairy fermentation bacteria. J. Food Prot., 51: 386 - 390.

El-Sayed, S.M., H.S. El-Sayed, H.H.Salama and El-Nor, S.A. (2017). Improving the nutritional value and extending shelf life of labneh by adding Moringa oleifera oil. Int. $\mathbf{J}$. Dairy Sci., 12: 81 - 92.

FAO/WHO (2001). Report on joint FAO/WHO expert consultation on evaluation of health and nutritional properties of probiotics in food including powder milk with live lactic acid bacteria. Farbreaktionen zur Joghurt-Untersuchung.

Milchwissensehaft, 9: 330.

Ghalem, B.R. and B. Zouaoui (2013). Microbiological, physico-chemical and sensory quality aspects of yoghurt enriched with Rosmarinus officinalis oil. African Biotechnol., 12: 192 - 198.

Ghazvini, R.D., E. Kouhsari, E. Zibafar, S.J. Hashemi, A. Amini and F. Niknejad (2016). Antifungal activity and aflatoxin degradation of Bifidobacterium bifidum and Lactobacillus fermentum against toxigenic Aspergillus parasiticus. The Open Microbiol. J., 10: 197 - 201.

Gün, Ö. and N.D. Işıklı (2007). Effect of fat and non-fat dry matter of milk and starter type, on the rheological properties of set during the coagulation process. of Food Int. J. food Sci. Technol., 42: 352 - 358.

Hamdan, I.Y., Jr, J.E. Kunsman and D.D. Deanne (1971). Acetaldehyde production by combined yogurt cultures. J. Dairy Sci., 54: 1080 - 1082.

Hamed, A. M., S. H. Taha, A. A. Darwish and E. Aly (2020). Antioxidant activity and some quality characteristics of buffalo yoghurt fortified with peanut skin extract powder. J. Food Sci.and Technol., 1-10.

Ibrahim, A.H. (2017). Studies on the effect of using inulin on chemical and physicochemical properties of set yoghurt. M.Sc. Thesis, Fac. Agric., Suez Canal Uni., Egypt.

Ismail, M.M., G.A. Ghoneem, N.A. ElBoraey, M.M. Tabekha and H.F. Elashrey (2017). Manufacture of biolabneh using ABT culture and Buffalo and soy milk mixtures. J. Microbiol., Biotechnol. Food Sci., 6: 1237-1245.

Kailasapathy, K. and S. Rybka (1997). L. acidophilus and Bifidobacterium spp. - their therapeutic potential and survival in yogurt. Austr. J. Dairy Technol., 52: 28 - 35.

Kebary, K. M. K., A. H. El-sonbaty, A. N. Zedan and Hweda A. El-Sayed (2008). Impact of bifidobacteria on flavoured low fat stirred youghurt quality.Proc. Of the $3^{\text {rd }}$ International Conference on Food Sci. and Nutrition, Cairo, Egypt, November 3-5, 2008, pp. 160-179.

Kebary, K.M.K., R.M. Badawi, A.I. Hamed and N.S. Omar (2010). Preparation and properties of novel functional yoghurt from buffalo milk. Proc. $11^{\text {th }}$ Egyptian Conf. Dairy Sci. Techol., pp. 463 - 478.

Khodear, M.M. (2018). Using of certain fat replacers in manufacture of some dairy products. Ph.D. Thesis, Fac. Agric., Assuit Uni., Egypt.

Less, G.J. and G.R. Jago (1969). Method for the Estimation of acetaldehyde in culture dairy products. Australian. J. Dairy Tech., 24: 5 - 181.

Ling, A.R. (1963). A Text book of Dairy Chemistry, Vol. 2, Practical $3^{\text {th }}$ Ed. Champman and Hall, Ltd., London.

Lorca, G.L., G.F. de Valdez and A. Ljungh (2002). Characterization of the proteinsynthesis dependent adaptive acid tolerance response in Lactobacillus acidophilus. J. Mol. Microbiol. Biotechnol., 4: 525 - 532.

Mahdian, E. and M.M. Tehrani (2007). Evaluation the effect of milk total solids on the relationship between growth and activity of starter cultures 
and quality of concentrated yoghurt. Agric. and Environ. Sci., 2: 587 - 592.

Mailam, M.A. (2015). Studies on the use of milk concentrates in mozzarella cheese manufacture. Ph.D. Thesis, Dairy Sci. and Tech., Fac. Agric., Ain Shams Uni., Egypt.

Martin, J.H. and K.M. Choe (1992). Selection of bifidobacteria for use as dietary adjusts in cultured dairy foods. 1-Tolerance to $\mathrm{pH}$ of youghurt. Cult. Dairy prod. J., 27: 21 - 26.

Mohamed, S.H.S., F.L. Seleet, B. Azzat, B. Abd El Khalek and F.A. Fathy (2015). Effect of wheat germ extract on the viability of probiotic bacteria and properties of labneh cheese. . Res. Pharm. Biol. Chem. Sci., 6: 674 - 652.

Nasser, A., A.S. El-Sisi and N.B. El-Gamil (2017). Enhancement of labneh quality by adding essential oil and aqueous extracts of peppermint Egypt. J. Agric., 95: 1193 - 1204.

Nergiz, C. and A.K. Seckin (1998). The losses of nutrients during the production of strained (torba) yoghurt. Food Chem., 61: 13 - 16.

Nsabimana, C., B.O. Jiang and R. Kossah (2005). Manufacturing, properties and shelf life of labneh: a review. Int. J. Dairy Technol., 58: 129 - 137.

Ołdak, A., D. Zielińska, A. Rzepkowska and D. Kołożyn-Krajewska (2017). Comparison of antibacterial activity of Lactobacillus plantarum strains isolated from two different kinds of regional cheeses from Poland: oscypek and korycinski cheese. BioMed Res. Int., pp. 1 - 10.

Omer, R.H. and A.H. Eltinay (2009). Changes in chemical composition of camel's raw milk during storage. Pakistan J. Nutr., 8 : 607 610.

Radi, N.A.M. and A.A. Abdelmonem (2017). A Study on the Antifungal
Effects of Lactobacillus Spp. on Candida Species. The Egyptian J. Med. Microbiol., 38: 1 - 5.

Rasic, J.L. (1987). Nutritive value of yogurt. Cult. Dairy Prod. J. (USA).

Robinson, R.K. and A.Y. Tamime (1994). Manufacture of yogurt and other fermented milks. In Robinson RK (Ed.). Modern dairy technology, Advances in milk products. London: Elsevier Appl. Sci., 2: 1 - 48.

Russo, P., C. Fares, A. Longo, G. Spano and V. Capozzi (2017). Lactobacillus plantarum with broad antifungal activity as a protective starter culture for bread production. Foods, 6: 1 - 9 .

Saad, S.A., H.H. Salama and H.S. ElSayed (2015). Manufacture of functional Labneh using Uf-retentate and artichoke puree. Int. J. Dairy Sci., 10: 186 - 197.

Salem, A.S., W.M. Salama, A. Hassanein and H.M. El-Ghandour (2013). Enhancement of nutritional and biological values of labneh by adding dry leaves of moringa oleifera as innovative dairy products. World. Appl. Sci. J., 22: 1594 - 1602.

Salem, M.M.E., M.A.M. Abd El-Gawad, F.A.M. Hassan and B.A. Effat (2007). Use of synbiotics for production of functional low fat Labneh. Pol. J. Food Nutr. Sci., 57: 151-159.

Samona, A. and R.K. Robinson (1991). Enumeration of bifido-bacteria In dairy products. J. Soc. Dairy Tech., 44 (3):64-66.

Shaker, R.R., B. Obeidat and M.A. AbuIshmais (2002). Influence of coagulum $\mathrm{pH}$ at draining on the quality and yield of concentrated yogurt (labneh). Egyptian. J. Dairy Sci., 30: 27 - 34.

Sharal, O.M., N. S. Mehanna, K. El-Shafei and A. E. Metwally (1996). Effect of using different starters on quality of labneh. Annals of Agricultural 
Science. Cairo: Ain-Shams University, 41: 901 - 912.

Soad, H.T., E.S. Girgis, E.S. Amer and E.S. Abd El-Moeety (1997). Effect of milk fat substitution with vegetable oils on the quality attributes of labneh. Egyptian J. Dairy Sci., 25: 193 - 203.

Steel, R.G.D. and J.H. Torrie (1980). Principles and procedures of statistics. A biometrical approach. $2^{\text {nd }}$ Ed. McGraw-Hill Book Co., New York

Tamime, A.Y. and R.K. Robinson (1999). Yoghurt Sciences and Technology CRC Press, Boca Raton, FL.

Tamime, A.Y. and R.L. Robinson (1983). Yoghurt Science and Technology. Pergamon Press, Oxford, U.K.
Thabet, H.M., Q.A. Nogaim, A.S. Qasha, O. Abdoalaziz and N. Alnsheme (2014). Evaluation of the effects of some plant derived essential oils on shelf life extension of Labneh. Merit Res. J. Food Sci. Technol., 2: 8 - 14.

Ventling, B.L. and V.V. Mistry (1993). Growth characteristics of bifidobacteria in ultrafiltered milk. J. Dairy Sci., 76 (4): 962 - 971.

Yu, Z., X. Zhang, S. Li, C. Li, D. Li and Z. Yang (2013). Evaluation of probiotic properties of Lactobacillus plantarum strains isolated from Chinese sauerkraut. World Journal of Microbiology and Biotechnology, 29(3): 489-498. 
تحسين خواص اللبنة وفوائدها الصحيه باستخدام البكتريا الداعمة للحيوية

\author{
خميس محمد كامل كعباري(")، كمال محمد كمالي(")، محمود أحمد ميلم(†)،

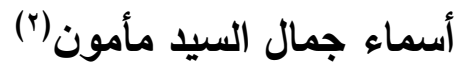

(1) قسم علوم وتكنولوجيا الالبان - كلية الزراعه -جامعة المنوفيه- شبين الكوم -جمهورية مصر العربيه

(ץ) قسم بحوث الالبان - معهر بحوث وتكنولوجيا الأغذية- مركز البحوث الزراعية

الملخص العربي

اللبنه تعتبر واحده من اشهر المنتجات المتخمره في منطقة الثرق الأوسط وبدأ انتاجها واستهلاكها يتزيد حديثا في السوق المصري ونظرا للفوائد الصحيه المتعدده للبكتريا الداعمة للحيويه فقد اهتمت الأبحاث حديثا بمحاولة إضافتها لمنتجات الالبان بغرض زيادة فوائها الصحيه لذلك.

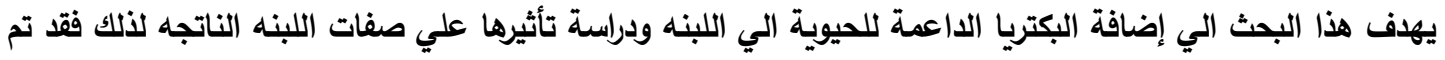
تصنيع خمس معاملات من اللبنه ز المعامله الاولي وهي الكونترول صنعت باستخدام بكتريا اليوجورت المعروفه (C)وكذلك

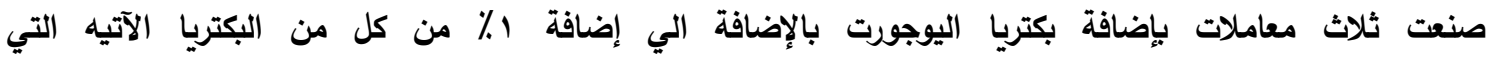

(T.acidophilus(T1), Bifidobacterium bifidum (T2), and L.plantarum(T3) أما المعامله الخامسة (T4) صنعت بإضافة بكتريا اليوجورت بالإضافة الي إضافة سبr. . . من كل من البكتريا الثلاث

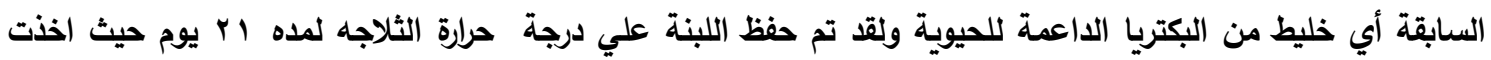

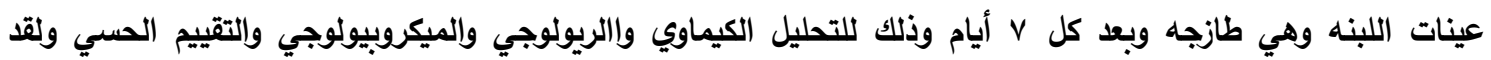

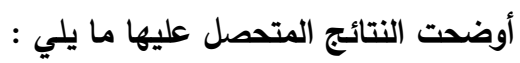

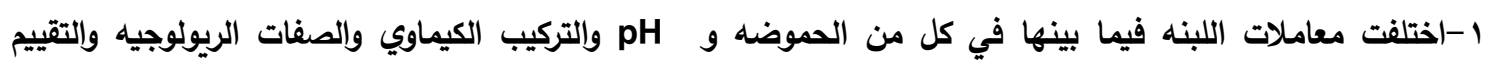

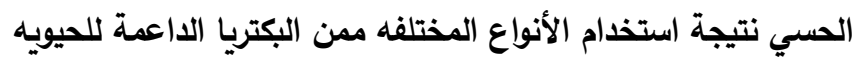

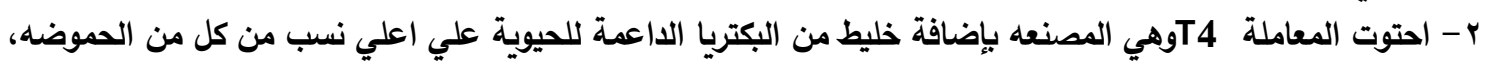

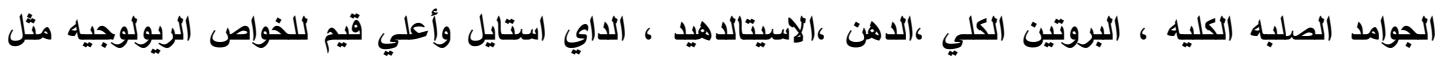
Hardness, Adhesiveness, Cohesiveness, Springiness, Gumminess and Chewiness وكانت متفاوتة من المعامله T3 المصنعة بإضافة L.plantarum اكثر العينات قبولا ؛ - إزدادت نسب كل من الحموضه والجوامد الصلبه الكليه والدهن والبروتين الكلي والرماد أثناء التخزين في حين انخفضت قيم pH واللاكتوز بتقدم فترة التخزين

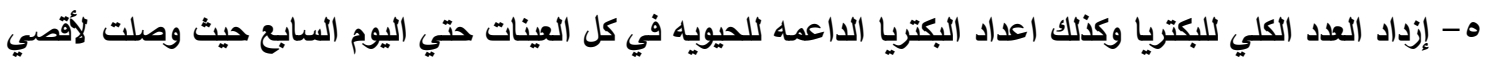

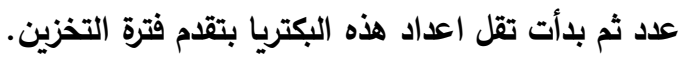

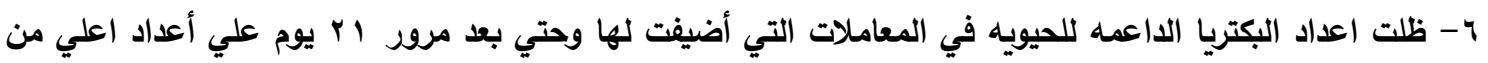

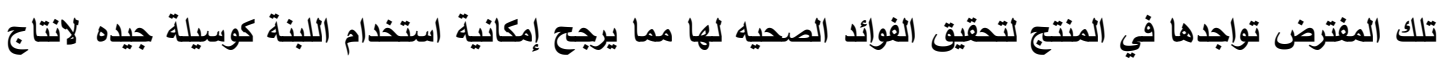
منتج وظيفي جيد داعم للحيويه.

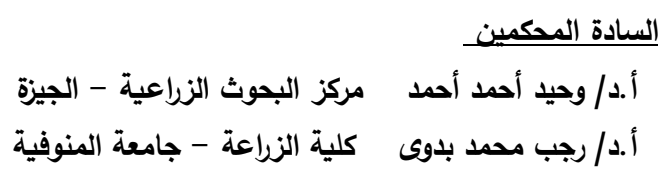

